\title{
Effect of Minor Alloying Elements (C, Ni, Cr, Mo) on the Long-Term Corrosion Behaviors of Ultrahigh-Strength Automotive Steel Sheet in Neutral Aqueous Environment
}

\author{
Hye Rin Bang', Jin-seong Park ${ }^{1}$, Hwan Goo Seong ${ }^{2}$, and Sung Jin Kim ${ }^{1, *}$ \\ ${ }^{I}$ Department of Advanced Materials Engineering, Sunchon National University, Suncheon 57922, Republic of Korea \\ ${ }^{2}$ POSCO Technical Research Laboratories, Gwangyang 57807, Republic of Korea
}

\begin{abstract}
This study examined the effects of minor alloying elements (C, Ni, Cr, and $\mathrm{Mo}$ ) on the long-term corrosion behaviors of ultrahigh-strength automotive steel sheets with a tensile strength of more than $1800 \mathrm{MPa}$. A range of experimental and analytical results showed that the addition of $\mathrm{Ni}$, $\mathrm{Cr}$, and $\mathrm{Mo}$ decreased the corrosion current density and weight loss in electrochemical and immersion tests, respectively, in a neutral aqueous condition. This suggests that the minor addition of elements to steel can result in improved corrosion resistance even for long-term immersion periods. This is closely associated with the formation of thin and stable corrosion scale on the surface, which was enriched with the alloying elements $(\mathrm{Ni}, \mathrm{Cr}$, and $\mathrm{Mo})$. On the other hand, their beneficial effects did not persist during the prolonged immersion periods in steel with a higher $\mathrm{C}$ content, suggesting that the beneficial effects of the minor addition of $\mathrm{Ni}$, $\mathrm{Cr}$, and Mo were overridden by the detrimental effects of a higher $\mathrm{C}$ content as the immersion time was increased. Based on these results, lower $\mathrm{C}$ and the optimal use of $\mathrm{Ni}, \mathrm{Cr}$, and $\mathrm{Mo}$ are suggested as a desirable alloy design strategy for developing ultrahigh-strength steel sheets that can be exposed frequently to a neutral aqueous environment.
\end{abstract}

(Received August 17, 2021; Accepted November 18, 2021)

Keywords: ultrahigh-strength steel, carbon, nickel, chromium, molybdenum, corrosion

\section{1. 서 론}

세계적인 탄소중립 정책의 일환으로, 대기 중 $\mathrm{CO}_{2}$ 가스 배출량 규제가 엄격해지고 있다. 이에 대한 대책으로 제철 및 자동차 산업계에서는 연비 절감 및 탑승객의 안정성을 동시에 확보할 수 있는 초고강도 강재개발 및 적용에 대한 관심이 높아지고 있다 [1-4]. 특히, dual phase강 [5], transformation-induced plasticity (TRIP)강 [6], twinning-

- 방혜린: 학사과정, 박진성: 박사과정, 성환구: 연구원, 김성진: 교수 *Corresponding Author: Sung Jin Kim

[Tel: +82-61-750-3557, E-mail: sjkim56@scnu.ac.kr]

Copyright (C) The Korean Institute of Metals and Materials induced plasticity (TWIP)강 [7] 등과 같이 고강도와 함 께 우수한 인성을 갖는 강재개발에 대한 다양한 연구가 진 행되고 있으며, 현재 $1.5 \mathrm{GPa}$ 이상의 인장강도를 갖는 초 고강도급 강재가 자동차용 부품 내 적용되고 있다.

일반적으로, 철강소재의 초고강도급 강도확보를 위한 기 술적 전략은 결정립 미세화 [8], 미세 석출물 형성 [9], 급 냉을 통한 마르텐사이트 조직 확보 [10] 등에 기초하고 있 다. 현재, $1.8 \mathrm{GPa}$ 이상의 인장강도 확보를 위해서는 일정 함량 이상의 $\mathrm{C}$ 첨가가 필요한 실정이다. 하지만 $\mathrm{C}$ 함량 증가에 의한 강화 전략은 기지조직 내 석출되는 $\mathrm{Fe}_{3} \mathrm{C}$ 의 분율 증가와 함께, 소재 내 잔류응력 증가로 귀결되어 강 재의 내식성 및 수소취화 저항성을 저하시킬 수 있다 
[11]. 내식성 측면에서, 석출 탄화물은 기지조직 대비 전기 화학적 전위가 높아 마이크로 갈바닉 효과에 따른 기지금 속의 양극용해를 촉진하는 것으로 알려져 있다 [12]. 또한, 높은 내부 잔류응력은 $\mathrm{Fe}$ 원자간 결합력을 약화시키게 되 고 부식반응에 대한 활성화에너지 장벽을 낮춰 강재의 부 식저항성을 약화시키는 원인으로 지적된 바 있다 [13]. 한 편, 수소취화 저항성 측면에서는, 조대한 크기의 석출 탄화 물 및 내부 잔류응력은 수소원자의 트랩 현상에 기여하여, 내부 수소 용해도 증가를 가져와 취성파괴저항성을 감소시 킬 수 있다 [14]. Akiyama et al. [15]와 Hwang et al. [16]에 의해 수행된 선행연구에 따르면 강재가 중성 수용 액 환경 내 노출된 조건에서도 부식반응을 통한 미량의 수 소원자 발생이 가능하다고 보고하였다. 또한, 경한 특성을 갖는 마르텐사이트 조직의 경우, 취화/균열을 야기하는 임 계 수소량이 연질의 페라이트 조직 대비 낮은 수준으로, 미량의 수소원자 유입에도 불구하고 쉽게 균열을 야기하는 것으로 보고되고 있다 [17]. 따라서, 강재의 내식성 향상을 통한 표면 부식반응의 억제효과는 향후 수소지연파괴에 대 한 저항성을 향상시키는 것으로 판단할 수 있다. 강재의 표면 부식반응 억제를 위해 미량의 합금성분을 제어하거나 도금 및 도장과 같은 표면처리가 수행될 수 있는데, 최적 합금설계에 기반을 둔 방식전략은 표면 후처리에 요구되는 추가 공정비용 및 후처리 시 야기되는 다양한 문제들을 배 제할 수 있기 때문에 산업적용 용이성 측면에서 유리할 수 있다. 뿐만 아니라, 합금성분 제어는 내식성 및 수소취화저 항성 뿐 아니라 기계적 물성 향상의 복합효과를 기대할 수 도 있다. 인장강도 $1.8 \mathrm{GPa}$ 이상의 초고강도 강재 개발을 위한 선행연구는 주로 기계적 물성 확보에 초점을 맞추어 이루어져 왔으며 [18], 중성 수용액 환경 내 강재 표면에 형성되는 부식생성물의 특성분석을 기반으로 장기 내식성 을 논의하는 연구는 현저히 부족한 실정이다.

따라서, 본 연구는 실제 산업적 활용이 가능한 수준에서, 상이한 합금원소를 첨가한 자동차용 초고강도급 강재를 대 상으로 $3.5 \% \mathrm{NaCl}$ 환경 내 부식거동을 분석하고자 하였 고 이를 토대로, 장기적인 측면에서 우수한 내식성 확보를 위한 바람직한 합금설계의 방향을 제시하고자 한다.

\section{2. 실험 방법}

\section{1 시편준비 및 미세조직 분석}

본 연구에 활용된 대상 소재는 $1.8 \mathrm{GPa}$ 이상의 인장강도 를 갖는 초고강도급 강재(최종두께: $2 \mathrm{~mm}$ )로 열간 및 냉 간압연 공정 등의 제조 프로세스는 동일하되, $\mathrm{C}, \mathrm{Ni}, \mathrm{Mo}$
Table 1. Chemical composition of the tested samples

\begin{tabular}{ccccccc}
\hline & $\mathrm{C}$ & $\mathrm{Mn}$ & $\mathrm{Cr}$ & $\mathrm{Mo}$ & $\mathrm{Ni}$ & $\mathrm{Cu}$ \\
\hline S1 & $0.4 \sim 0.5$ & $0.9 \sim 1.0$ & 0.1 & $<0.1$ & 0.3 & $<0.1$ \\
S2 & $0.4 \sim 0.5$ & $0.9 \sim 1.0$ & 0.1 & $<0.1$ & 0.9 & $<0.1$ \\
S3 & $0.5 \sim 0.6$ & $0.9 \sim 1.0$ & 0.2 & 1.0 & 0.9 & 0.1 \\
S4 & $0.3 \sim 0.4$ & $0.9 \sim 1.0$ & 0.5 & 0.5 & 0.9 & $<0.3$ \\
\hline
\end{tabular}

및 $\mathrm{Cr}$ 성분의 첨가량이 상이한 네 가지 시편( $\mathrm{S} 1, \mathrm{~S} 2, \mathrm{~S} 3$, $\mathrm{S} 4)$ 으로 구성되었다. 각 시편에 대한 화학적 조성은 표 1 에 나타내었다. 우선, 템퍼드 마르텐사이트 조직 확보를 위 해 $930^{\circ} \mathrm{C}$ 에서 7 분간 유지하여 수냉 후 $200^{\circ} \mathrm{C}$ 에서 30 분 동안 템퍼링을 수행하였다.

미세조직 관찰을 위해 시편을 마운팅 한 후 $\mathrm{SiC}$ paper \#2400까지 기계적 연마 및 $1 \mu \mathrm{m}$ 까지의 미세연마를 수행하 였다. 이후, $5 \%$ Nital $\left(5 \mathrm{ml} \mathrm{HNO}_{3}+95 \mathrm{ml}\right.$ ethanol) 용액 에서 대략 3 5초 간 화학적 에칭을 수행하였다. 이후, 전 계 방사형 주사전자현미경(Field emission scanning electron microscopy, FE-SEM)을 활용하여 미세조직을 관찰하였고, $0.04 \mu \mathrm{m}$ 까지의 미세연마 후 전자후방산란회절(Electron backscatter diffraction, EBSD) 분석을 통해 시편별 조직 내 래스 기반의 결정립 크기를 비교하였다. EBSD 분석은 $20 \mathrm{kV}$ 의 가속전압, $1 \mathrm{nA}$ 의 빔전류, $50 \mathrm{~nm}$ 의 측정간격 조 건으로 수행되었다. 또한, 각 시편의 경도 측정을 위해 비 커스 경도기를 활용하였다. 경도 측정은 시험 하중 $0.5 \mathrm{kgf}$ 으로 15 초동안 유지하였으며, 각 시편당 12 회 측정하여 평 균값을 도출하였다.

\section{2 전기화학적 분극거동 분석}

전기화학적 부식거동 분석을 위해 flat cell을 사용하여 $3.5 \% \mathrm{NaCl}$ 용액 내에서 전기화학적 동전위분극 (Electrochemical potentiodynamic polarization), 임피던스 (Electrochemical impedance spectroscopy, EIS) 및 선형 분극저항(Linear polarization resistance, LPR) 실험을 수 행하였다. 기본적으로 전기화학적 실험은 작업전극 (Working electrode, WE), 상대전극(Counter electrode, $\mathrm{CE}$ ) 및 기준전극(Reference electrode, RE)으로 이루어진 3전극 시스템을 사용하였으며, 기준전극과 상대전극은 각 각 포화 칼로멜 전극(Saturated calomel electrode, $\mathrm{SCE}$ ) 과 mesh 형태의 백금전극으로 구성되었다. 동전위 분극 의 경우 개방회로전위(Open circuit potential, OCP) 대 비 $-0.1 \sim 1.4 \mathrm{~V}$ 의 전위구간을 $0.2 \mathrm{mV} / \mathrm{s}$ 의 속도로 증가시키 며, 각 분극전위에 따라 도출되는 전류밀도를 측정하였다. 임피던스 실험은 시편을 용액 내 20 분 및 96 시간 동안 침 
지 후, $\mathrm{OCP}$ 기준 $\pm 10 \mathrm{mV}$ 의 전위를 교류방식으로 인가하 고 $100,000 \sim 0.01 \mathrm{~Hz}$ 의 frequency 범위에서 도출되는 분극 저항을 비교하고자 하였고, 이에 대한 정량분석을 위해 등 가회로를 기반으로 fitting이 수행되었다. LPR 실험은 시편 을 용액 내 96시간 동안 침지 후 OCP 대비 $-0.02 \mathrm{~V}$ $0.02 \mathrm{~V}$ 전위 구간을 $0.2 \mathrm{mV} / \mathrm{s}$ 의 속도로 증가시키며 도출되 는 전류밀도를 측정하였다. 이후, 실험적으로 획득한 curve (Semi-log 형태)를 Wagner-Traud [19] (식 (1)) 및 SternGeary equation [20] (식 (2))을 통해 fitting 하여 시편 별 부식전류밀도(Corrosion current density, $\left.i_{\text {corr }}\right)$ 를 도출하 였다.

$$
\begin{aligned}
& i=i_{\text {corr }}\left[\exp \left(\frac{2.303\left(E-E_{\text {corr }}\right)}{\beta_{a}}\right)-\exp \left(\frac{-2.303\left(E-E_{\text {corr }}\right)}{\beta_{c}}\right)\right] \\
& i_{\text {corr }}=\frac{\beta_{a} \beta_{c}}{2.303 \cdot R_{P} \cdot\left(\beta_{a}+\beta_{c}\right)}
\end{aligned}
$$

여기서 $i$ 는 fitting된 이론적 전류밀도 $\left(\mathrm{A} / \mathrm{cm}^{2}\right), i_{\text {corr }}$ 는 부 식 전류밀도 $\left(\mathrm{A} / \mathrm{cm}^{2}\right), E_{c o r r}$ 는 부식 전위 $\left(\mathrm{V}_{\mathrm{SCE}}\right), \beta_{a}, \beta_{c}$ 는 각 각 양극, 음극 tafel 기울기(V/decade), $R_{P}$ 는 분극 저항 $\left(\Omega \cdot \mathrm{cm}^{2}\right)$ 을 나타낸다.

이후, curve fitting을 통해 도출된 $i_{\text {corr }}$ 을 아래 식 (3)과 같이 단위변환하여 corrosion rate (MPY)을 정량적으로 도 출하였다 [21].

$$
\mathrm{MPY}=\frac{i_{c o r r} \cdot \Lambda \cdot \varepsilon}{\rho}
$$

여기서 $\Lambda$ 는 $1.2866 \times 10^{-5}$ (Equivalents's'mil) (Coulombs' $\mathrm{cm}^{\cdot}$ years $)^{-1}, \varepsilon$ 은 철의 당량(27.92, Equivalent weight), $\rho$
는 철의 밀도 $\left(7.87 \mathrm{~g} / \mathrm{cm}^{3}\right)$ 를 나타낸다.

전기화학 실험의 경우, 데이터의 재현성 확보를 위해 3 번의 반복 실험을 수행하였으며 대표성 있는 데이터를 제 시하였다.

\section{3 무게감량 및 부식생성물 분석}

부식환경 내 무게감량을 측정하기 위해 각 시편(표면적: $31.5 \mathrm{~cm}^{2}$ )을 $\mathrm{SiC}$ paper \#1200까지 연마하여 $3.5 \% \mathrm{NaCl}$ 용액 내 4주간 침지 후 꺼내어 에탄올에서 초음파 세척하 였다. 이후, 전자저울을 통해 침지 전 대비 침지 후 감량 된 무게를 측정하였으며 식 (4)을 통해 시간에 따른 무게 감량(Weight loss)을 비교하였다.

$$
\text { Weight loss }\left(\mathrm{g} / \mathrm{cm}^{2}\right)=\frac{W_{1}-W_{2}}{A}
$$

여기서, $W_{1}$ 는 침지 전 무게 $(\mathrm{g}), W_{2}$ 는 침지 후 무게 $(\mathrm{g})$, $A$ 은 시편 표면적 $\left(\mathrm{cm}^{2}\right)$ 을 나타낸다.

실험의 재현성 확보를 위해 각 실험 조건에 3 개의 시편 이 활용되었으며, 총 3 번의 반복 실험을 수행하였다. 또한, 무게감량 결과는 측정 값 중 최대값과 최소값을 제외한 나 머지의 평균값으로 나타내었다.

또한, 침지 후 강재 표면에 형성된 부식 생성물의 단면 을 FE-SEM으로 관찰하였고 에너지 분산 분광분석법 (Energy dispersive X-Ray spectroscopy, EDS)을 통해 성 분분석을 수행하였다. 아울러, 부식생성물의 종류 및 부식 생성물의 깊이에 따른 성분분포를 이해하기 위해 X-ray 회 절분석(X-Ray diffraction, $\mathrm{XRD)}$ 및 글로우 방전 분광분 석(Glow discharge spectrometer, GDS)이 추가로 수행되
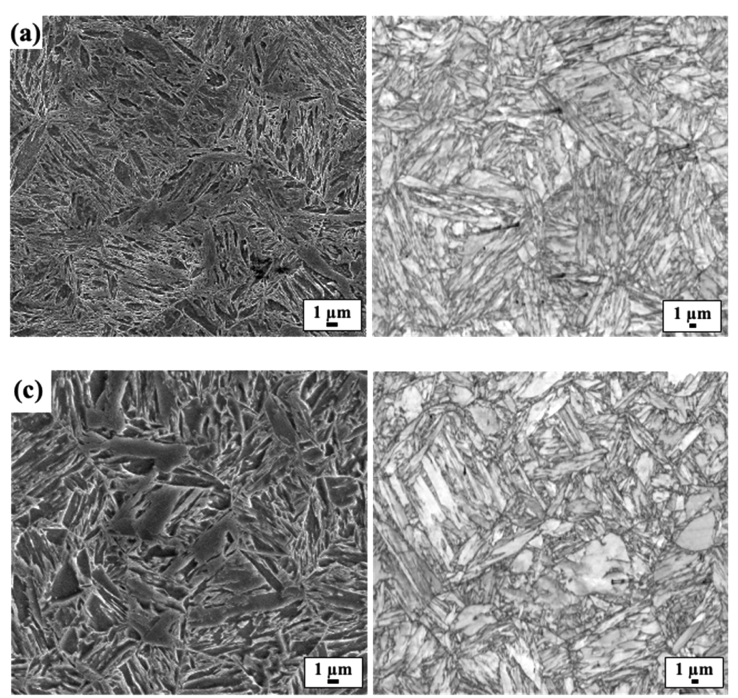
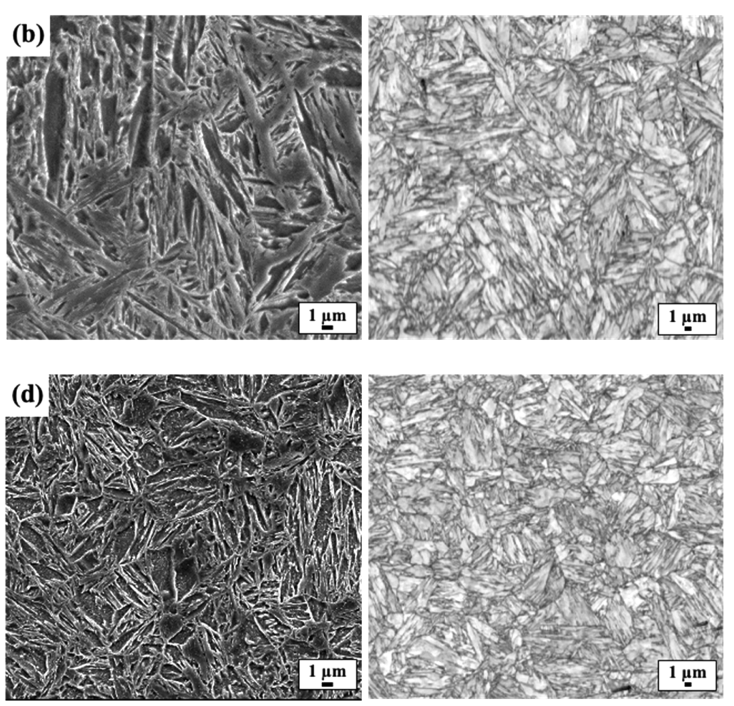

Fig. 1. Microstructure images of the samples observed by FE-SEM and EBSD: (a) S1, (b) S2, (c) S3, and (d) S4. 
었다.

\section{3. 결과 및 고찰}

\section{1 미세조직 관찰}

그림 1은 열처리 이후 FE-SEM 및 $\mathrm{EBSD}$ 를 통해 관찰 된 시편 별 미세조직 형상을 나타낸다. 네 시편 모두 급냉 을 통해 형성된 래스 타입의 템퍼드 마르텐사이트 조직이 관찰되었다. 제시된 배율에서, 거시적으로 관찰가능한 탄화 물 및 첨가된 합금성분에 기인한 석출물은 없었다. 다만, 선행연구 [22]에 따르면 급냉 후 $100 ~ 200{ }^{\circ} \mathrm{C}$ 의 온도구간 에서 tempering이 수행된 경우, 거시적 관찰이 용이한 조 대한 크기의 구상 cementite $\left(\mathrm{Fe}_{3} \mathrm{C}\right)$ 의 석출이 어려우며 수 -수십 $\mathrm{nm}$ 크기의 준안정 탄화물인 $\varepsilon$-carbide $\left(\mathrm{Fe}_{2.4} \mathrm{C}\right)$ 가 주 로 래스 계면에 석출된다고 보고되고 있다. 그러나, 래스 계면에 석출되는 $\mathrm{Fe}_{2.4} \mathrm{C}$ 는 그 크기가 매우 미세하여 $\mathrm{FE}$ $\mathrm{SEM}$ 수준의 분해능에서는 관찰이 불가하며 보다 높은 분 해능의 TEM 분석이 요구된다. 초고강도급 강재 내 TEM 으로 관찰된 미세 $\mathrm{Fe}_{2.4} \mathrm{C}$ 는 선행 연구 [23]에서 논의된 바 있으므로 본 연구에서는 제외하기로 하였다. 각 시편의 결 정립 크기 및 비커스 경도의 평균값을 그림 2에 나타내었 다. 타 원소의 함량은 동일하되, $\mathrm{Ni}$ 함량 차이가 두드러지 는 시편 $\mathrm{S} 1, \mathrm{~S} 2$ 의 경우, $\mathrm{Ni}$ 첨가에 따라 래스 결정립 크 기가 감소함을 보였다. 이는 $\mathrm{Ni}$ 함량 증가 $(\mathrm{S} 1 \rightarrow \mathrm{S} 2)$ 에 따 라 기지조직 내 석출되는 미고용 시멘타이트의 잔존비율이 증가한다는 선행연구결과 [24]를 토대로 입계 피닝효과와 연관지어 이해될 수 있다. 즉, $930^{\circ} \mathrm{C}$ 에서 동일시간 austenitizing 처리함에도 불구하고, $\mathrm{Ni}$ 의 첨가로 인한 미고 용 시멘타이트의 잔존은 결정립크기를 감소시킬 수 있으나, 기지조직 내 $\mathrm{C}$ 의 불충분한 고용을 야기하여 결국 시편의 강도 및 경도 감소에도 영향을 미칠 수 있을 것으로 사료 된다. 따라서, S1 대비 S2의 낮은 비커스 경도 값(그림 2) 은 이러한 맥락에서 이해될 수 있다. 한편, S1 및 S2 대 비 $\mathrm{Cr}, \mathrm{Mo}$ 가 추가로 첨가된 $\mathrm{S} 3$ 및 $\mathrm{S} 4$ 시편의 경우, 유 사 혹은 미세한 수준의 결정립 크기를 나타내었으나, 상대 적으로 높은 비커스 경도를 나타내었다. 이는 $\mathrm{Cr}$ 및 $\mathrm{Mo}$ 의 첨가에 기인한 고용강화 [25]와 함께 경화능 증가 [26]의 결과로 짐작되며, 특히, $\mathrm{S} 1$ 및 $\mathrm{S} 2$ 대비 낮은 $\mathrm{C}$ 함량을 갖 는 S4 시편의 경우가 $\mathrm{S} 1$ 및 $\mathrm{S} 2$ 시편 대비 상대적으로 높 은 경도 값을 나타내었다는 점에서 초고강도급 강재 개발에 있어 $\mathrm{C}$ 함량 증가 이외에 $\mathrm{Cr}$ 및 $\mathrm{Mo}$ 의 미량 첨가에 의한 강도 향상 효과 또한 기대할 수 있을 것으로 사료된다.

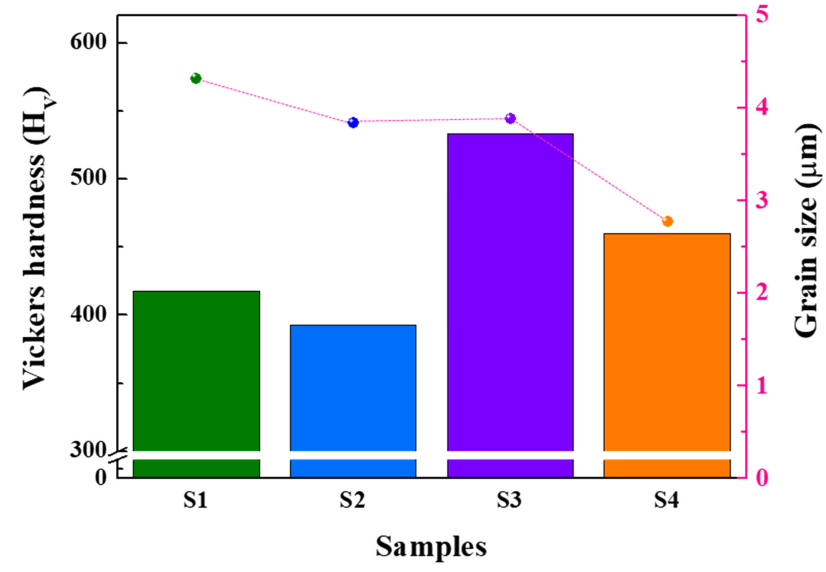

Fig. 2. Vickers hardness and grain size of the samples.

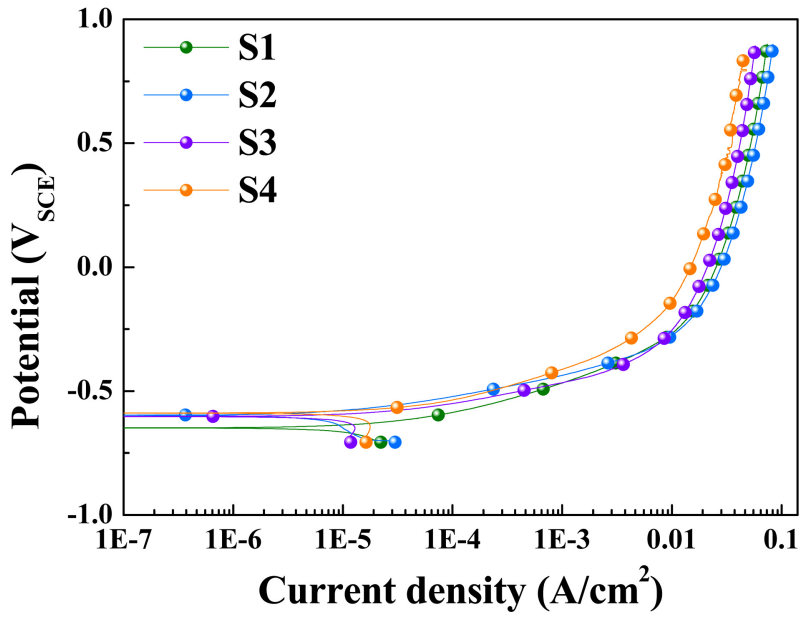

Fig. 3. Potentiodynamic polarization curves of the samples, measured in a $3.5 \% \mathrm{NaCl}$ solution.

\section{2 전기화학적 분극 실험 및 부식 거동 관찰}

그림 3은 전기화학적 동전위 분극 실험 결과를 나타낸다. $\mathrm{S} 4$ 를 제외한 시편의 경우 오차범위 내 양극용해 $(\mathrm{Fe} \rightarrow$ $\left.\mathrm{Fe}^{2+}+2 \mathrm{e}^{-}\right)$에 기인한 전류밀도 거동을 보이는 반면, $\mathrm{Cr}$ 과 $\mathrm{Mo}$ 가 첨가된 $\mathrm{S} 4$ 의 경우 구간 내 상대적으로 낮은 양극전 류밀도를 나타내었다. 하지만, 동전위 분극 실험 결과를 통 한 내식성 평가는 부식환경 내 노출되는 강재의 장기적 부 식특성을 판단하기에 제한적일 것으로 사료되어 부식환경 내 노출되는 시간을 증가시키며 변화되는 부식거동 분석을 위해 침지 20 분과 96 시간에서의 EIS 및 LPR 실험을 수 행하였고, 그 결과 및 전기화학적 변수 값을 각각 그림 4 와 5 및 표 2와 3에 나타내었다. 

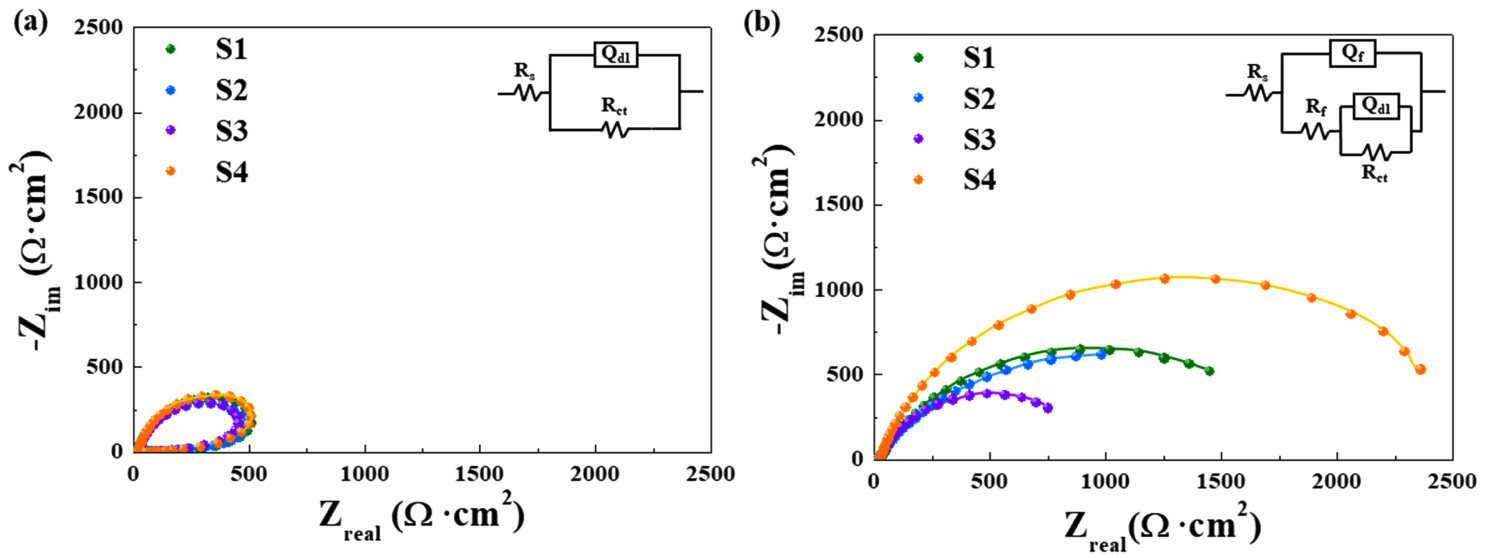

Fig. 4. EIS Nyquist plots of the samples, measured after (a) $20 \mathrm{~min}$ and (b) $96 \mathrm{~h}$ immersion in a $3.5 \% \mathrm{NaCl}$ solution.
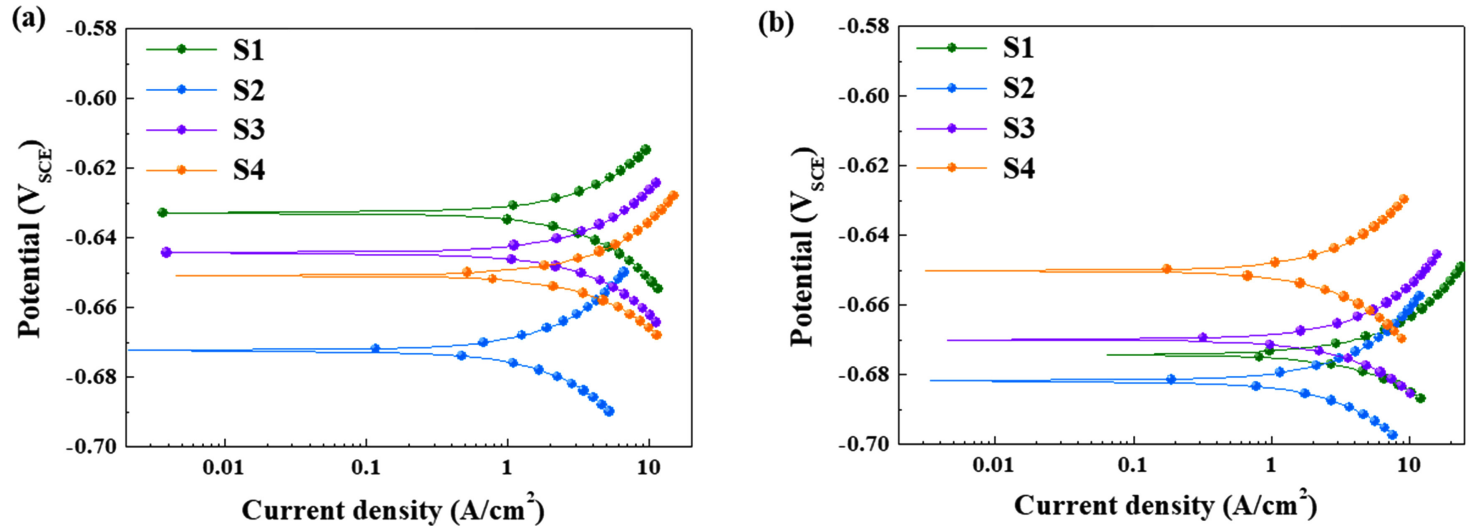

Fig. 5. LPR curves of the samples, measured after (a) $20 \mathrm{~min}$ and (b) $96 \mathrm{~h}$ immersion in a $3.5 \% \mathrm{NaCl}$ solution.

Table 2. Several electrochemical parameters obtained by curve-fitting to EIS Nyquist plots of the samples

\begin{tabular}{ccccccccc}
\hline & \multicolumn{4}{c}{20 min immersion } & \multicolumn{4}{c}{$96 \mathrm{~h}$ immersion } \\
Parameters & $\mathrm{S} 1$ & $\mathrm{~S} 2$ & $\mathrm{~S} 3$ & $\mathrm{~S} 4$ & $\mathrm{~S} 1$ & $\mathrm{~S} 2$ & $\mathrm{~S} 3$ & $\mathrm{~S} 4$ \\
\hline$Q_{f}$ & - & - & - & - & $1.99 \mathrm{E}-3$ & $3.69 \mathrm{E}-3$ & $3.06 \mathrm{E}-3$ & $5.29 \mathrm{E}-4$ \\
$R_{f}$ & - & - & - & - & $4.83 \mathrm{E}+1$ & $2.10 \mathrm{E}+2$ & $1.25 \mathrm{E}+1$ & $2.29 \mathrm{E}+1$ \\
$Q_{d l}$ & $1.86 \mathrm{E}-2$ & $2.26 \mathrm{E}-2$ & $2.30 \mathrm{E}-2$ & $2.28 \mathrm{E}-2$ & $1.04 \mathrm{E}-4$ & $8.71 \mathrm{E}-5$ & $7.22 \mathrm{E}-3$ & $9.01 \mathrm{E}-4$ \\
$R_{c t}$ & 700 & 700 & 700 & 750 & $1.82 \mathrm{E}+3$ & $1.69 \mathrm{E}+3$ & $9.82 \mathrm{E}+2$ & $2.62 \mathrm{E}+3$ \\
\hline
\end{tabular}

Table 3. Several electrochemical parameters obtained by curve-fitting to LPR data of the samples

\begin{tabular}{ccccccccc}
\hline & \multicolumn{4}{c}{20 min immersion } & \multicolumn{4}{c}{96 h immersion } \\
Parameters & $\mathrm{S} 1$ & $\mathrm{~S} 2$ & $\mathrm{~S} 3$ & $\mathrm{~S} 4$ & $\mathrm{~S} 1$ & $\mathrm{~S} 2$ & $\mathrm{~S} 3$ & $\mathrm{~S} 4$ \\
\hline$E_{\text {corr }}$ & -0.674 & -0.672 & -0.644 & -0.651 & -0.561 & -0.682 & -0.67 & -0.65 \\
$\beta_{a}$ & 0.09 & 0.1 & 0.058 & 0.085 & 0.052 & 0.042 & 0.044 & 0.074 \\
$\beta_{c}$ & 0.069 & 0.12 & 0.12 & 0.12 & 0.03 & 0.025 & 0.034 & 0.12 \\
$i_{\text {corr }}$ & $6.19 \mathrm{E}-6$ & $2.2 \mathrm{E}-6$ & $4.16 \mathrm{E}-6$ & $4.86 \mathrm{E}-6$ & $1.33 \mathrm{E}-5$ & $3.61 \mathrm{E}-6$ & $4.86 \mathrm{E}-6$ & $3.34 \mathrm{E}-6$ \\
\hline
\end{tabular}

침지 초기(그림 4(a)) Nyquist plot의 경우, 전체적으로 차이를 보이지 않았다. 반면, 침지 96시간 후(그림 4(b)) $R_{p}$ 값이 $500 \Omega \cdot \mathrm{cm}^{2}$ 이하의 낮은 수준이며, 시편들 간 큰 측정된 Nyquist plot에서는 동전위 분극 실험 결과와 유사 
하게 $\mathrm{S} 4$ 시편의 $R_{p}$ 값이 타 시편 대비 상대적으로 크게 측정되었으며, $\mathrm{C}$ 함량이 가장 높은 $\mathrm{S} 3$ 시편의 $R_{p}$ 값이 가 장 낮게 측정되었다. 또한, 동일 침지 기간에 측정된 $\mathrm{LPR}$ 결과(그림 5), 침지기간이 증가함에 따라 전반적으로 $E_{\text {corr }}$ 이 감소하고 $i_{c o r r}$ 이 증가하였으나, S4 시편의 경우 침지시 간이 증가함에도 극초기(20분)와 유사한 거동을 나타내었 다. 그림 6은 96시간까지 측정된 $\mathrm{MPY}$ 의 평균 값을 나타 내는데 $\mathrm{S} 1>\mathrm{S} 3>\mathrm{S} 2>\mathrm{S} 4$ 의 순서로 부식속도가 도출되었다. $\mathrm{C}$ 함량이 가장 높은 $\mathrm{S} 3$ 의 내식성이 $\mathrm{S} 1$ 대비 상대적으로 낮게 도출된 것을 토대로, 미량 첨가된 $\mathrm{Ni}, \mathrm{Cr}$ 및 $\mathrm{Mo}$ 이 내식성을 향상시키는 데에 기여하는 것으로 해석할 수 있 다. H. Sato et al. [27]는 강재 내 $5 \mathrm{wt} \%$ 수준의 $\mathrm{Ni}$ 첨 가는 표면 농화층을 형성하고 $\mathrm{Fe}$ 기반 부식생성물의 기공 율 감소 및 안정도 향상을 통해 강재의 내식성을 향상시킬 수 있음을 보고하였다. 또한, 부식생성물 내 $\mathrm{Fe}$ 자리에 $\mathrm{Ni}$ 이 대신 치환되어 보다 치밀한 부식생성물 형성하고, 부 식생성물 내 $\gamma-\mathrm{FeOOH}$ 상 대비 내식성 향상에 효과적인 $\alpha-\mathrm{FeOOH}$ 의 형성을 촉진시킨다고 알려져 있다 [28]. $1 \sim 3 \mathrm{wt} \%$ 수준의 $\mathrm{Cr}$ 첨가의 경우, 강재 표면에 $\mathrm{Cr}_{2} \mathrm{O}_{3}$ 와 같은 치밀한 형태의 부식생성물을 축적하여 외부에서 유입 되는 부식 유발 인자와의 접촉을 차단함으로써 강재의 내 식성을 향상시키며, $\mathrm{Fe}^{3+}$ 이온이 $\mathrm{Cr}^{3+}$ 이온으로 치환됨에 따라 표면에 안정적인 $\mathrm{FeCr}_{2} \mathrm{O}_{4}$ 가 형성되는 것으로 보고된 바 있다 [29]. S. B. Shin et al. [30]의 연구에 따르면, 고강도 저합금(High-Strength Low-Alloy)강 내 첨가되는 $\mathrm{Mo}(0.2 \mathrm{wt} \%)$ 의 경우, 균일한 부식생성물 형성을 촉진하고 $\mathrm{MoO}_{4}{ }^{2-}$ 의 음이온 이중층을 형성하여 $\mathrm{Fe}$ 의 양극용해 및 부 식성 이온의 접근을 억제시키는 것으로 보고되었다. 이상

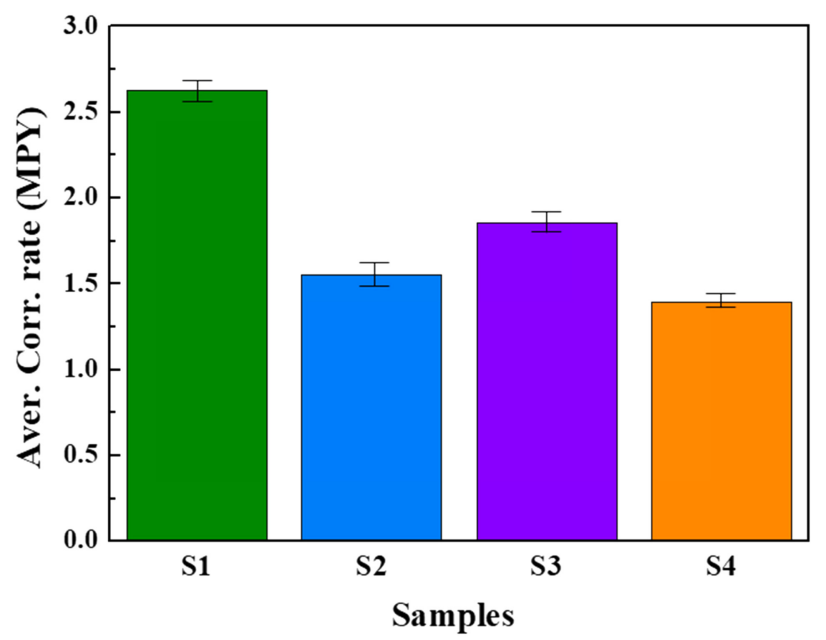

Fig. 6. Corrosion rate in MPY, obtained by curve-fitting to LPR data of the samples.

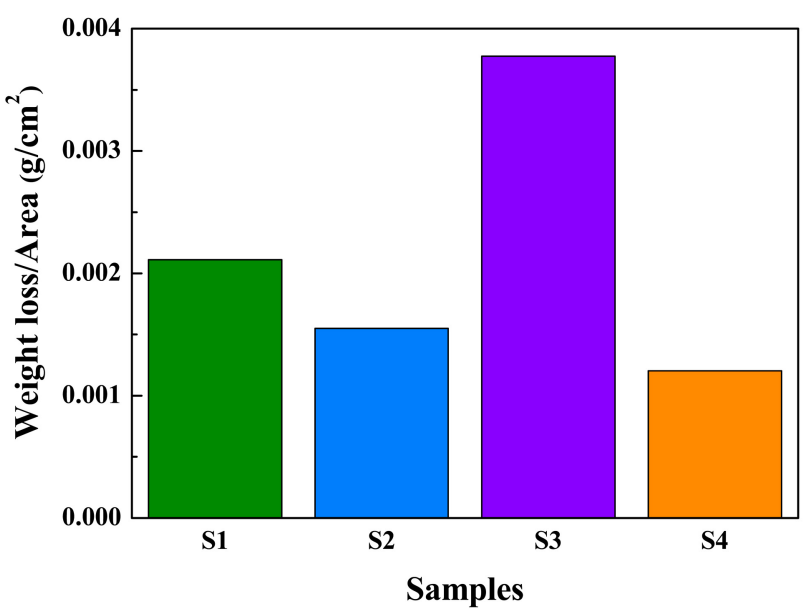

Fig. 7. Weight loss of the samples after immersion in a 3.5\% $\mathrm{NaCl}$ solution for four weeks.

논의된 바와 같이 강재 내 미량 첨가된 합금원소 $(\mathrm{Ni}, \mathrm{Cr}$ 및 $\mathrm{Mo}$ )는 본 연구의 대상소재인 초고강도강의 내식성 향 상에 충분히 기여할 수 있을 것으로 판단되나, 앞서 평가 된 전기화학적 실험만으로는 장기침지를 통한 부식생성물 의 특성변화 측면과 내식성 간 연관성이 부족하다는 판단 으로 보다 장기 침지를 통한 무게감량 및 부식생성물의 특 성 분석을 추가로 진행하였다.

\section{3 장기적 침지에 따른 무게감량 및 부식생성물 분석}

그림 7은 부식 환경 내 4주간 침지 후 측정한 무게감량 결과를 보여준다. 우선, 동일한 $\mathrm{C}$ 함량을 갖는 $\mathrm{S} 1$ 및 $\mathrm{S} 2$ 시편의 경우, 첨가된 $\mathrm{Ni}$ 함량이 높을수록 무게감량이 낮게 측정되었다. 이는, $\mathrm{Ni}$ 의 첨가가 부식환경 내 장기적 노출 에도 상대적으로 우수한 부식특성을 유지하는 것으로 해석 될 수 있다. 또한, 단기 침지실험 후 가장 높은 내식성을 보였던 S4 시편의 경우 장기 침지를 통한 무게감량 측정 결과에서도 동일하게 가장 우수한 내식성이 나타났다. 한 편, $\mathrm{C}$ 함량이 가장 높았으나, $\mathrm{Cr}$ 및 $\mathrm{Mo}$ 의 첨가를 통해 초·중기( 96시간) 부식반응이 일부 제어된 것으로 판단된 $\mathrm{S} 3$ 시편의 경우, 장기 침지결과, 내식성이 가장 낮게 도출 된 것을 토대로, 부식환경 내 노출 시간이 장기화됨에 따 라 $\mathrm{Cr}$ 및 $\mathrm{Mo}$ 첨가에 따른 내식성 향상의 긍정적 효과 대비 높은 $\mathrm{C}$ 함량에 따른 부정적 효과가 보다 커진 것으 로 사료되었다. 즉, 높은 $\mathrm{C}$ 함량의 강재 $\mathrm{S} 3$ 강재 $(0.2 \mathrm{Cr}$ $+1 \mathrm{Mo}$ )에서 장기 내식성을 확보하기 위해 요구되는 $\mathrm{Cr}$ 함 량이 보다 높아져야 함을 짐작할 수 있다. 또한, $\mathrm{Cr}$ 함량 이 부족한 상태에서 Mo 함량만을 높이는 방식으로는 장기 내식성 확보에 제한적임을 암시한다. 제시된 장기 내식성 

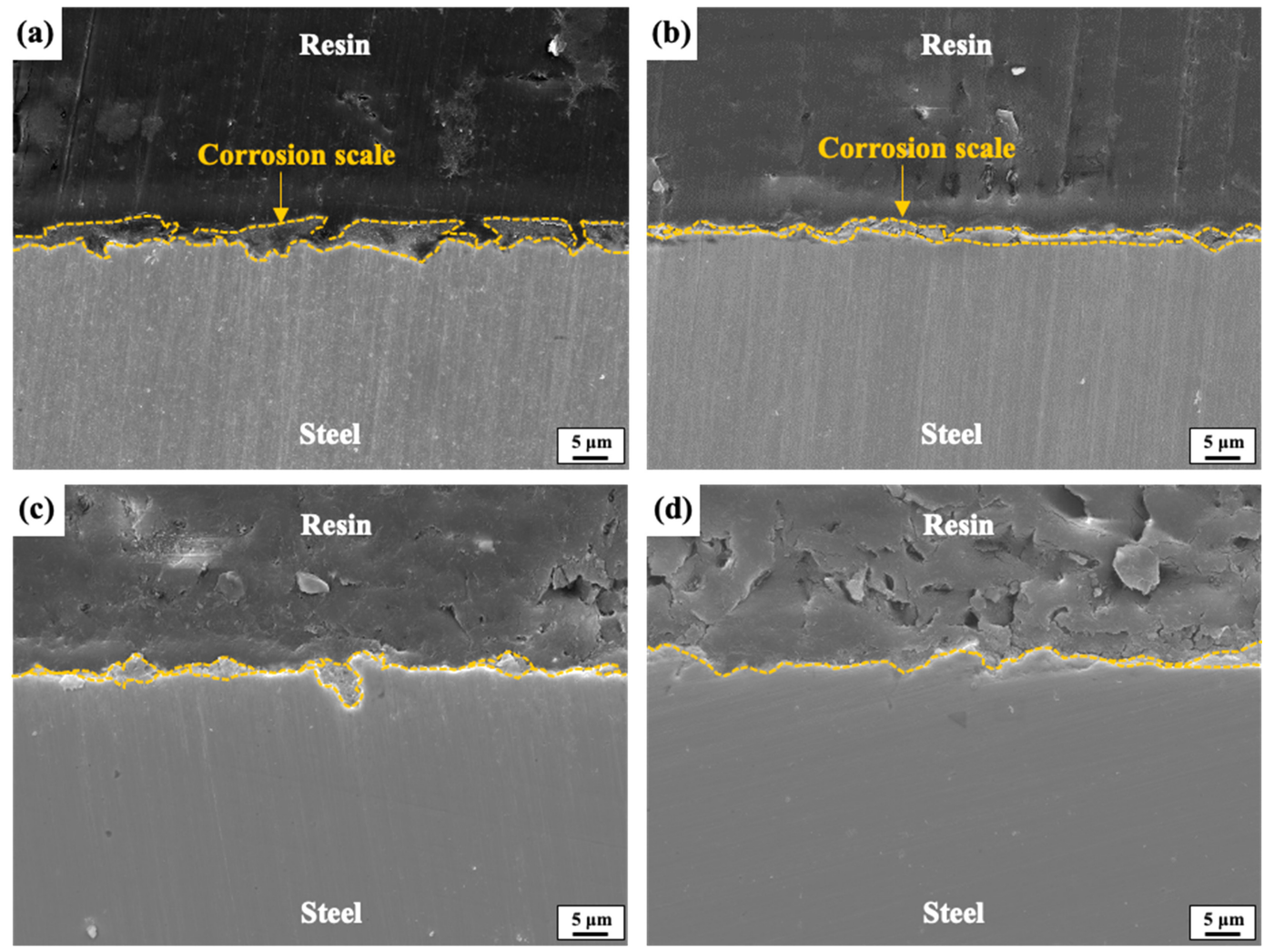

Fig. 8. Cross-sectional morphologies of (a) S1, (b) S2, (c) S3, and (d) S4 after immersion in a 3.5\% $\mathrm{NaCl}$ solution for one week.

결과를 강재 표면에 형성된 부식생성물의 특성변화 측면에 서 이해하고자 우선, 1 주 및 4주간 침지 후 표면에 축적 된 부식생성물의 단면을 관찰하였다. 그림 $8(\mathrm{a})$ 와 (b)에서 보이는 바와 같이, 1 주간 침지 후 $\mathrm{S} 1$ 및 $\mathrm{S} 2$ 시편 대비 $\mathrm{Cr}$ 및 $\mathrm{Mo}$ 가 첨가된 시편 $(\mathrm{S} 3$ 및 $\mathrm{S} 4)$ 의 부식생성물층은 매

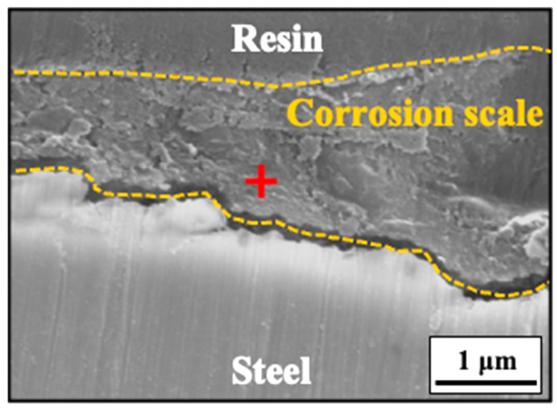

\begin{tabular}{|c|c|c|}
\hline Element & wt\% & at\% \\
\hline OK & 10.66 & 29.22 \\
\hline ClK & 01.36 & 01.67 \\
\hline FeK & 88.38 & 69.09 \\
\hline
\end{tabular}

(a)
우 얇은 수준으로 관찰되었다. 하지만, $\mathrm{C}$ 함량이 높은 S3 시편의 경우, $\mathrm{S} 4$ 시편 대비 표면 부식형상이 다소 불균일 하고 기지 금속의 국부적 손상 영역이 관찰되었다. 한편, $\mathrm{Ni}$ 첨가 함량만 상이한 $\mathrm{S} 1$ 및 $\mathrm{S} 2$ 시편의 경우, $\mathrm{S} 1$ 시편 은 S2 시편 대비 생성물의 두께가 두껍고, 불균일한 기지

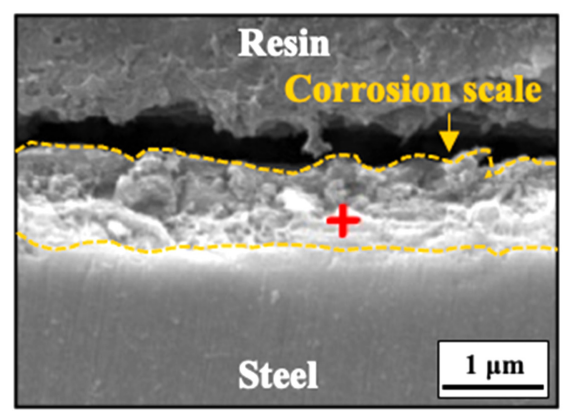

\begin{tabular}{|c|c|c|}
\hline Element & wt\% & at\% \\
\hline OK & 08.16 & 23.76 \\
\hline FeK & 83.56 & 69.67 \\
\hline NiK & 08.28 & 06.57 \\
\hline
\end{tabular}

(b)

Fig. 9. Magnified image of cross-section morphologies of (a) $\mathrm{S} 1$ and (b) $\mathrm{S} 2$ after immersion in a 3.5\% $\mathrm{NaCl}$ solution for one week, and EDS analysis of corrosion scale formed on each sample. 
/생성물 계면이 관찰되었다. 그림 9는 $\mathrm{EDS}$ 를 통한 $\mathrm{S} 1$ 및 $\mathrm{S} 2$ 시편 표면에 형성된 부식생성물의 성분분석 결과를 나 타내는데, $\mathrm{Ni}$ 함량이 증가함에 따라 표면에 형성된 부식생 성물 내 $\mathrm{Ni}$ 의 함량이 높게 측정되었다. 이는 $\mathrm{Ni}$ 첨가가 표면 $\mathrm{Ni}$ 농화층 형성 및 축적된 부식생성물 내 $\alpha-\mathrm{FeOOH}$ 상분율 증가를 야기하며 부식생성물 내 공공 감소 및 안정 도 향상에 따라 내식성을 향상시킨다는 선행연구와 유사한 맥락으로 이해될 수 있다. 보다 장기간(4주간)의 침지결과 (그림 10), 1 주 침지 경우 대비 전반적으로 부식생성물이 두껍게 성장하였음을 알 수 있다. 상대적으로 얇은 생성물 및 균일한 기지/생성물 계면이 형성된 $\mathrm{S} 4$ 와 달리 $\mathrm{S} 1$ 및 $\mathrm{S} 3$ 시편의 경우, 비교적 두껍고 불균일한 생성물층이 관찰 되었다. 또한, $\mathrm{S} 2$ 시편은 $\mathrm{S} 1$ 대비 부식생성물 층 내 균일 도는 양호한 수준으로 판단할 수 있으나, 기지/생성물 계 면의 고르지 못한 형상이 특징적으로 나타났다. 이는 선행 연구결과 [31]를 토대로, $\mathrm{Ni}$ 첨가 초고강도 강재의 열처리 시, 내부산화물의 형성과 국부적 $\mathrm{Ni}$ 농화/고갈 영역 형성 과 밀접한 관련이 있을 것으로 사료된다. 또한, 가장 두껍 고, 높은 불균일도를 보이는 $\mathrm{S} 3$ 시편의 경우를 고려하면, 높은 $\mathrm{C}$ 함량의 첨가는 내부 격자 뒤틀림, 전위밀도 및 잔 류응력과 같은 조직 내 결함 수준 증가 [32-34]에 기인하
여, 표면에 안정적인 부식생성물의 형성 저해와 밀접한 연 관성이 있는 것으로 판단된다. XRD 분석(그림 11)을 토대 로, $\mathrm{Ni}$ 이 첨가된 $\mathrm{S} 2, \mathrm{~S} 3, \mathrm{~S} 4$ 에서, $\mathrm{NiO}$ 및 $\mathrm{NiFe}_{2} \mathrm{O}_{4}$ 상이 일부 형성되었을 것으로 예상되었으며, $\mathrm{Cr}$ 이 첨가된 $\mathrm{S} 3$ 및 $\mathrm{S} 4$ 에서는 $\mathrm{Fe}_{\mathrm{x}} \mathrm{Cr}_{3-\mathrm{x}} \mathrm{O}_{4}$ 상이 일부 형성되었을 것으로 사료된 다. 이는 대표적인 부식생성물인 $\mathrm{Fe}_{3} \mathrm{O}_{4}$ 상과 극히 유사한 $2 \theta$ 값을 가져 구분하기에 어려움이 있었다. 다만, 선행연구 에서는 X-Ray photoelectron spectroscopy (XPS) 분석을 통해 $3 \mathrm{wt} \%$ 의 $\mathrm{Ni}$ 및 $3 \mathrm{wt} \%$ 의 $\mathrm{Cr}$ 이 첨가된 강재 부식생 성물층 내 이와 같은 상이 형성됨이 보고된 바 있다 [2829]. 또한, $\mathrm{Fe}$ 계열 산화물의 $\mathrm{Fe}$ 자리에 $\mathrm{Cr}$ 및 $\mathrm{Ni}$ 이 부분 치환됨에 따라 입자크기 감소 [35-37]에 따른 치밀도 증가 에 기인하여 내식성 향상 가능성이 논의된 바 있다 $[31,38]$. 한편, $\mathrm{Cr}$ 및 $\mathrm{Mo}$ 가 첨가된 $\mathrm{S} 3$ 및 $\mathrm{S} 4$ 시편의 경 우, 전체적인 XRD peak의 intensity가 감소하는 경향을 보였다. 이는, $\mathrm{Fe}_{2} \mathrm{O}_{3}$ 및 $\mathrm{Fe}_{3} \mathrm{O}_{4}$ 와 같은 결정질의 부식생성 물이 아닌 $\mathrm{FeOOH}, \mathrm{Cr}_{2} \mathrm{O}_{3}, \mathrm{FeCr}_{2} \mathrm{O}_{4}$ 등과 같은 비정질 부식생성물의 형성과 관련이 있을 것으로 사료된다 [3944]. 본 연구 내 대상시편들 중 가장 우수한 내식성 및 얇 고 안정적인 부식생성물의 형상을 나타낸 S4 시편을 대상 으로, 부식생성물의 성분분석 결과(그림 12), 부식생성물
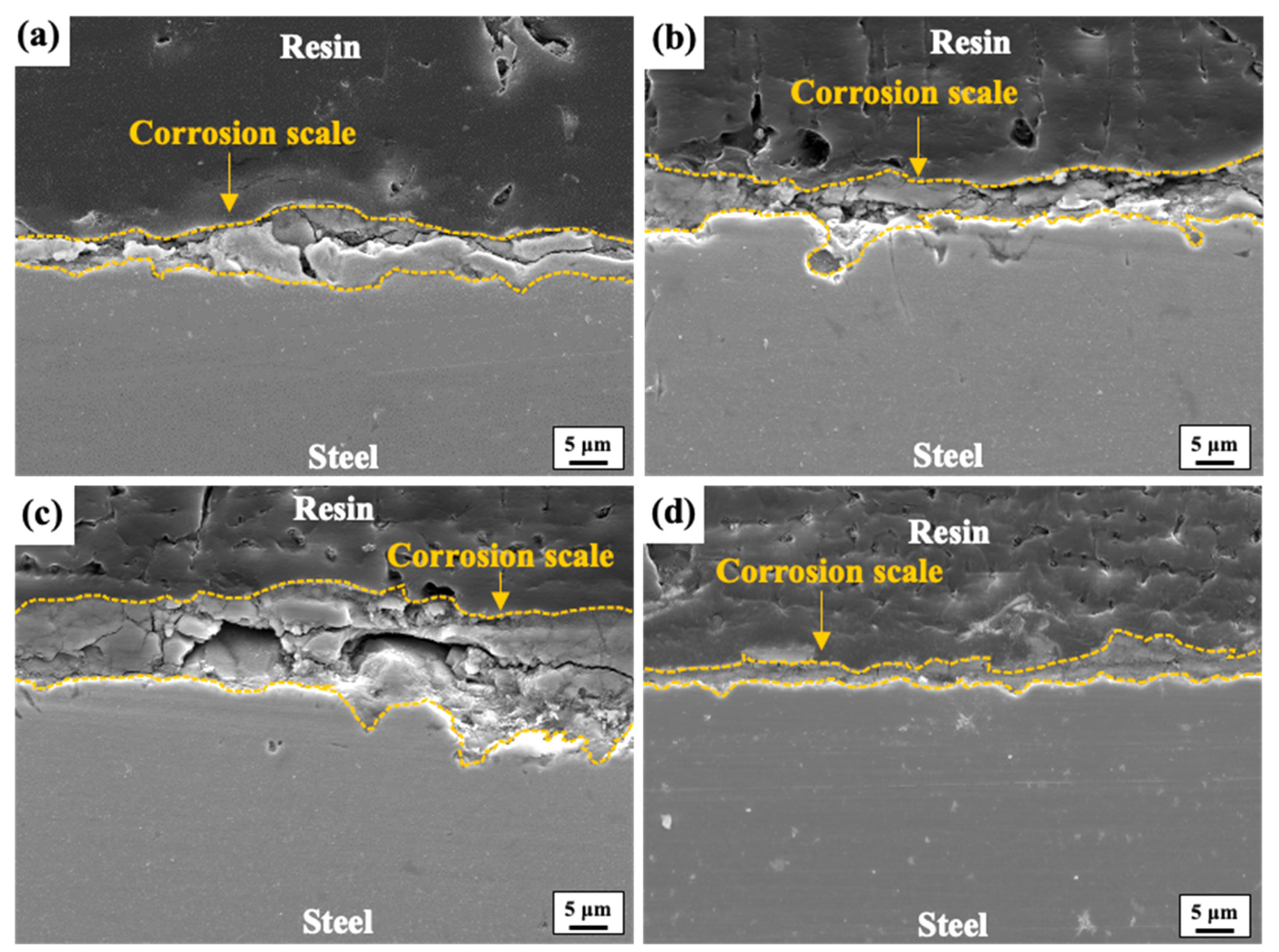

Fig. 10. Cross-section morphologies of (a) S1, (b) S2, (c) S3, and (d) S4 after immersion in a $3.5 \% \mathrm{NaCl}$ solution for four weeks. 


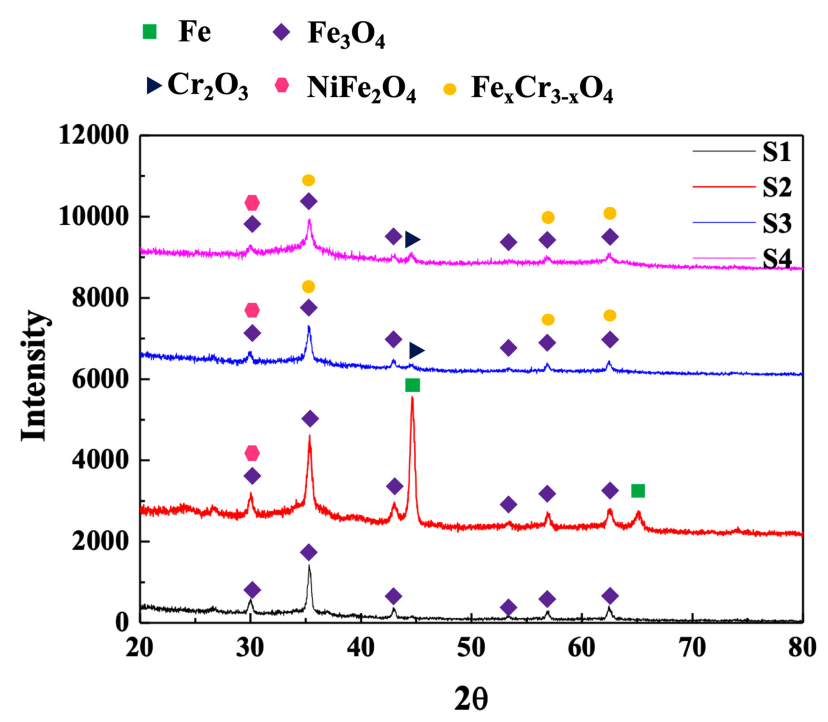

Fig. 11. XRD patterns, obtained by the thin film mode, of the samples after immersion in a $3.5 \% \mathrm{NaCl}$ solution for four weeks.

내부에 $\mathrm{Ni}, \mathrm{Cr}$ 및 $\mathrm{Mo}$ 의 성분농화가 나타났음을 확인하였 다. 이는 성분의 농화가 주로 기지/부식생성물 계면에서 이 루어졌음을 나타내는 GDS 분석결과(그림 13)를 통해서도 뒷받침된다.

일련의 실험 및 분석결과를 바탕으로, 초고강도급 강재 의 장기내식성 향상은 표면에 형성되는 부식생성물의 두께, 안정도 및 생성물/기지 계면의 형상변화 측면에서 이해될 수 있으며, 본 연구에서는 $\mathrm{C}$ 함량의 감소와 함께 $\mathrm{Cr}$ 을 기 반으로 $\mathrm{Mo}$ 및 $\mathrm{Ni}$ 성분의 최적화된 첨가로의 합금설계가 추천된다. 다만, 높은 $\mathrm{C}$ 함량에 따른 부정적효과를 상쇄시 킬 수 있는 임계 $\mathrm{Cr}$ 함량 및 $\mathrm{Cr}, \mathrm{Mo}, \mathrm{Ni}$ 각 성분의 단 독 및 복합 시너지효과 등의 규명에 대해서는 향후 추가연 구가 필요할 것으로 사료된다.

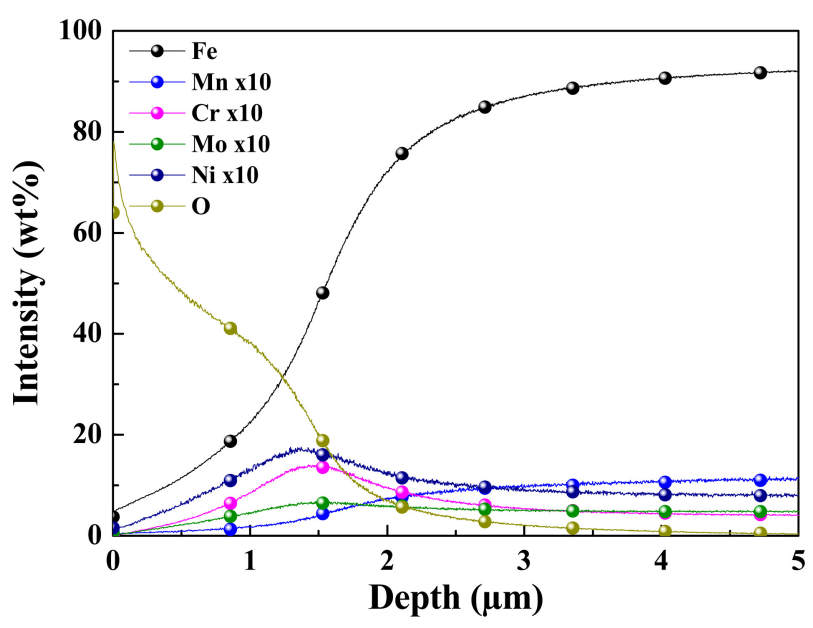

Fig. 13. Compositional depth-profile by GDS of S4 after immersion in a $3.5 \% \mathrm{NaCl}$ for four weeks.

\section{4. 결 론}

본 연구에서는 중성의 수용액 환경 내 노출되는 자동차 용 초고강도급 강재의 내식성 향상을 위한 바람직한 합금 설계의 방향을 제시를 목적으로 다양한 실험 및 분석이 진 행되었고, 주요 결론은 다음과 같이 요약된다.

1. 합금성분이 상이한 네 가지 시편의 미세조직은 래스 타입의 템퍼드 마르텐사이트 조직으로 구성되었고, 미량의 $\mathrm{Ni}$ 첨가는 래스 결정립 미세화를 가져올 수 있으나, 상대 적으로 낮은 경도 값을 나타내었다. 반면, 미량의 $\mathrm{Cr}$ 및 $\mathrm{Mo}$ 첨가를 통한 거시적 미세조직의 차이는 관찰되지 않았 으나, 경도 값 증가를 토대로 기계적 강화에 효과적인 것 으로 나타났다.

2. 전기화학적 부식실험 결과, $\mathrm{C}$ 함량의 증가가 내식성 저하를 유발할 수 있으나, 단기적으로는 $\mathrm{Cr}$ 및 $\mathrm{Mo}$ 의 부가 적인 첨가로 인해 부식속도를 일부 제어하는 것이 가능하 였다. $\mathrm{Ni}$ 함량 증가 또한 내식성 향상에 일부 기여하였고,

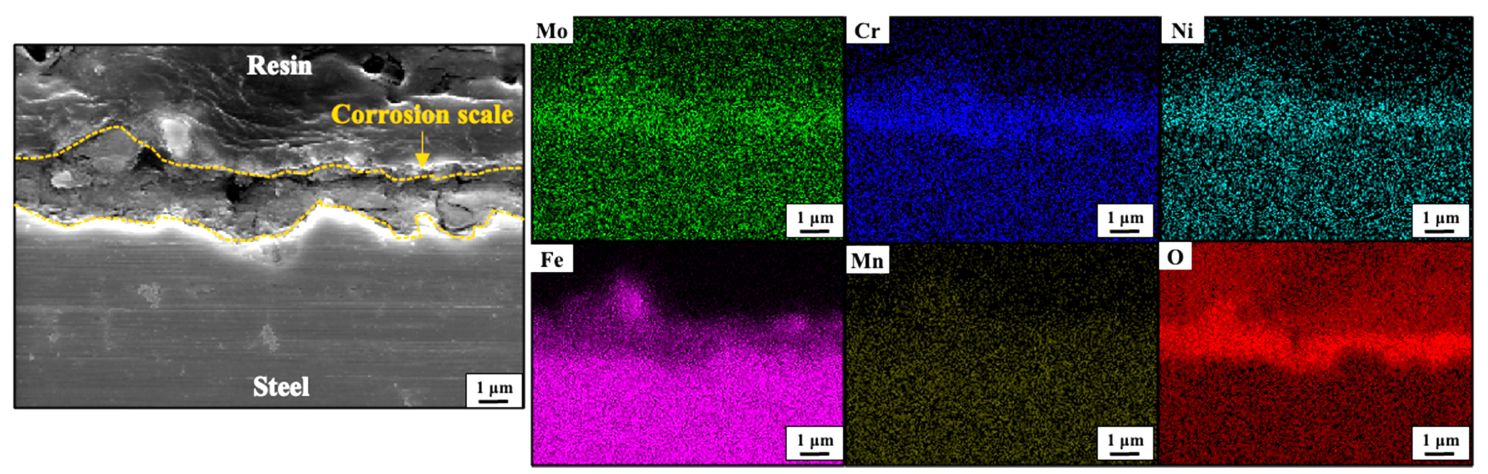

Fig. 12. EDS mapping analysis of a cross-section of $\mathrm{S} 4$ after immersion in a $3.5 \% \mathrm{NaCl}$ solution for four weeks. 
$\mathrm{C}$ 함량이 가장 낮고, $\mathrm{Cr}, \mathrm{Mo}$ 및 $\mathrm{Ni}$ 이 소량 첨가된 시편 의 경우 가장 높은 내식성을 나타내었다.

3. 부식환경 내 노출시간이 장기화됨에 따라 $\mathrm{C}$ 함량 증가 에 의한 내식성 저하효과가 $\mathrm{Cr}$ 및 $\mathrm{Mo}$ 첨가에 의한 내식성 항상효과를 상쇄하여 내식성이 크게 저하되었다. 반면 $\mathrm{C}$ 함 량이 낮은 경우 장기적으로도 $\mathrm{Cr}, \mathrm{Mo}$ 및 $\mathrm{Ni}$ 성분 첨가에 의한 긍정적 효과가 유지되었다. 이와 같은 장기 내식성의 변화는 표면에 형성된 부식생성물의 두께, 안정도, 성분농화 도 및 생성물/기지 계면의 균일도 등에 크게 의존하였다. 결 국, 본 연구를 통해 초고강도급 철강소재의 내식성 향상을 위해 $\mathrm{C}$ 함량의 저감과 함께 $\mathrm{Cr}$ 을 기반으로 $\mathrm{Mo}$ 및 $\mathrm{Ni}$ 성 분의 최적화된 첨가로의 합금설계가 추천된다.

\section{Acknowledgement}

This paper was supported in part by Sunchon National University Research Fund in 2020. (Grant number: 2020-0188). This work was also supported in part by the National Research Foundation of Korea (NRF) grant funded by the Korea government (MSIT) (No. 2019R1C1C1005007)

\section{REFERENCES}

1. M. Takita and H. Ohashi, Metall. Res. Technol. 98, 889 (2001).

2. J. Galán, L. Samek, P. Verleysen, K. Verbeken, and Y. Houbaer, Rev. Metal. 48(2), 118 (2012).

3. S. Takagi, Y. Togi, M. Yoshino, and K. Hasegawa, ISIJ Int. 52, 316 (2012).

4. H. Karbasian and A.E. Tekkaya, J. Mater. Process. Tech. 210, 2103 (2010).

5. J. F. d. S. Filho, C. A. S. d. Oliveira, N. Fonstein, O. Girina, F. J. F. Miranda, J. Drumond, E. A. Serafim, and C. R. M. Afonso, Mater. Res. 19(1), 258 (2016).

6. M. C. Jo, J. H. Choi, H. Lee, A. Zargaran, J. H. Ryu, S. S. Sohn, N. J. Kim, and S. Lee, Mater. Sci. Eng. A 740-741, 16 (2019).

7. J. K. Ren, Q. Y. Chen, J. Chen, and Z. Y. Liu, Mater. Sci. Eng. A 786, 139397 (2020).

8. M. Calcagnotto, D. Ponge, and D. Raabe, Mater. Sci. Eng. A 527, 7832 (2010).

9. Y. W. Kim, J. H. Kim, S. G. Hong, and C. S. Lee, Mater. Sci. Eng. A 605, 244 (2014).
10. K. Saeidi, D. L. Zapata, F. Lofaj, L. Kvetkova, J. Olsen, Zhijian, and F. Akhtar, Addit. Manuf. 29, 100803 (2019).

11. J. S. Park, H. G. Seong, and S. J. Kim, Corros. Sci. Tech. 18, 267 (2019).

12. D. N. Staicopolus, J. Electrochem. Soc. 110, 1121 (1963).

13. L. Bai, K. Jiang, and L. Gao, Mater. Res. 21, e20180166 (2018).

14. A. Trautmann, G. Mori, M. Oberndorfer, S. Bauer, C. Holzer, and C. Dittmann, Materials 13, 3604 (2020).

15. E. Akiyama, K. Matsukado, S. Li, and K. Tsuzaki, Appl. Surf. Sci. 257, 8275 (2011).

16. E. H. Hwang, S. M. Ryu, and S.J. Kim, Korean J. Met. Mater. 28, 428 (2018).

17. J. Venezuela, F. Y. Lim, L. Liu, S. James, Q. Zhou, R. Knibbe, M. Zhang, H. Li, F. Dong, M. S. Dargusch, and A. Atrens, Corros. Sci. 171, 108726 (2020).

18. M. C. Niu, L. C. Yin, K. Yang, J. H. Luan, W. Wang, and Z. B. Jiao, Acta Mater. 209, 116788 (2021).

19. C. Wagner and W. Traud, Z. Elektrochem. 44, 391 (1938).

20. M. Stern and A. L. Geary, J. Electrochem. Soc. 104, 56 (1957).

21. Y. Mehta, S. Trivedi, K. Chandra, and P. S. Mishra, J. Miner. Mater. Charact. Eng. 9, 855 (2010).

22. J. Krawczyk, P Bała, and J. Pacyna, J. Microsc. 237, 411 (2008).

23. E. H. Hwang, H. G. Seong, and S. J. Kim, Korean J. Met. Mater. 56, 570 (2018).

24. J. S. Park, H. G. Seong, J. K. Hwang, and S. J. Kim, Mater. Des. 193, 108877 (2020).

25. J. Gu, J. Li, R. Chang, and L. Li, Mater. Sci. Eng. A 766, 138386 (2019).

26. M. Yamada, L. Yan, E. Takaku, S. Ohsaki, K. Miki, K. Kajikawa, and T. Azuma, ISIJ Int. 54, 240 (2014).

27. H. Sato, M. Ito, K. Kashima, M. Kaneko, M. Nagasawa, and T. Doi, ISIJ Int. 60, 2024 (2020).

28. W. Wu, X. Cheng, J. Zhao, and X. Li, Corros. Sci. 165, 108416 (2020).

29. M. Sun, C. Du, Z. Liu, C. Liu X. Li, and Y. Wu, Corros. Sci. 186, 109427 (2021).

30. S. B. Shin, S. J. Song, Y. W. Shin, J. G. Kim, and B. J. Park, Mater. Trans. 57, 2116 (2016).

31. S. J. Kim, E. H. Hwang, J. S. Park, S. M. Ryu, D. W. Yun, and H. G. Seong, npj Mater. Degrad. 3, 1 (2019).

32. S. Morito, J. Nishikawa, and T. Maki, ISIJ Int. 43, 1475 (2003). 
33. J. Venezuela, Q. Zhou, Q. Liu, H. Li, M. Zhang, M. S. Dargusch, and A. Atrens, Mater. Today Commun. 17, 1 (2018).

34. S. Ding, S. Xiang, and X. Ba, ISIJ Int. 60, 2015 (2020).

35. Paul Scherrer Institute. Report No. 02-04 (Paul Scherrer Institute, 2002).

36. M.Yamashita, T. Shimizu, H. Konishi, J. Mizuki, and H Uchida, Corros. Sci. 45, 381 (2003).

37. M. Kimura, T. Suzuki, G. Shigesato, H. Kihira, and S. Suzuki, ISIJ Int. 42, 1534 (2002).

38. Y. J. Jeong, S. O. Kim, J. S. Park, J. W. Lee, J. K. Hwang, S. G. Lee, J. K. Choi, and S. J. Kim, npj Mater. Degrad. 5, 1 (2021).

39. S. Park, J. O. Baker, M. E. Himmel, P. A. Parilla, and D. K.
Johnson, Biotechnol. Biofuels 3, 3 (2010).

40. W. Wu, R. Hao, F. Liu, X. Su, and Y. Hou, J. Mater. Chem. A 1, 6888 (2013).

41. Y. Eom, M. Abbas, H. Noh, and C. Kim, $R C S A d v .6,15861$ (2016).

42. W. D. Chemelewski, H. C. Lee, J. F. Lin, A. J. Bard, and C. B. Mullins, J. Am. Chem. Soc. 136, 2843 (2014).

43. S. P. Narayanan, P. Thakur, A. P. Balan, A. A. Abraham, F. Mathew, M. Yeddala, T. Subair, C. Tiwary, S. Thomas, T. N. Narayanan, P. M. Ajayan, and M. M. R. Anantharaman, Phys. Status Solidi RRL 13, 1900025 (2019).

44. D. P. Nguyen, Q. T. Tran, X. S. Trinh, T. C. Hoang, H. N. Nguyen, and H. H. Nguyen, Adv. Nat. Sci.: Nanosci. Nanotechnol. 3, 015017 (2012). 